\title{
Amphibians
}

\section{FURTHER OBSERVATIONS OF BLUE-SPOTTED SALAMANDERS NEAR PINAWA, MANITOBA}

\section{PETER TAYLOR P.O. Box 597, Pinawa, MB, R0E 1 L0 Email: taylorp@granite.mb.ca}

The blue-spotted salamander (Ambystoma laterale), a small salamander with a maximum length of about 14 $\mathrm{cm}$ (Figures 1 and 2), approaches its northwestern range limit in southeastern Manitoba. ${ }^{1-5}$ Seasonal movements of this species between 2008 and 2010 in and near "Cameron woods", a 28-hectare patch of mixed-wood forest bounded by streets and roads at Pinawa, Manitoba, were described previously. ${ }^{4}$ Some features of these movements were surprising, especially the predominance of late-summer and fall observations, apparently involving all age classes (based on relative sizes) but with recent metamorphs predominating. Spring movements were sparse, with only eight of 194 salamanders being found in April or May. This contrasted with studies elsewhere, in which spring migration of adults to and from breeding ponds dominated the observed movements. ${ }^{6,7}$ It is therefore important to know whether the movements observed at Cameron woods are representative of Manitoba populations or (as seems more likely) specific to the site and/or the abnormally wet conditions during the study period.

On 19 April 2011, I found seven bluespotted salamanders crossing a paved road in a forested area about $12 \mathrm{~km}$ west of Pinawa. This immediately suggested a comparative study with the opportunity to sample spring movements in a less disturbed setting than Cameron woods. This article presents the results of nocturnal surveys at this new location in 2011 and 2012, with emphasis on distinguishing the movements of three age classes: metamorphs (young of the year), yearlings (second calendar year, sometimes called juveniles), and adults (third or later calendar year). Some new, comparative data are also presented for the Cameron woods study area in 2011 and 2012.

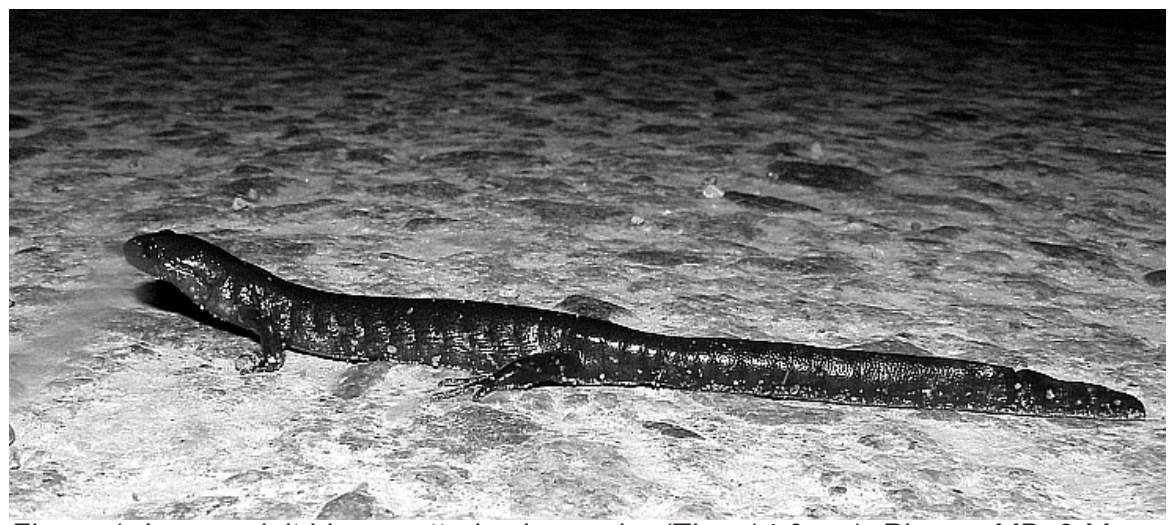

Figure 1: Large adult blue-spotted salamander $(T L=14.0 \mathrm{~cm})$, Pinawa MB, 9 May 2011 (as found on road).

-P. Taylor 


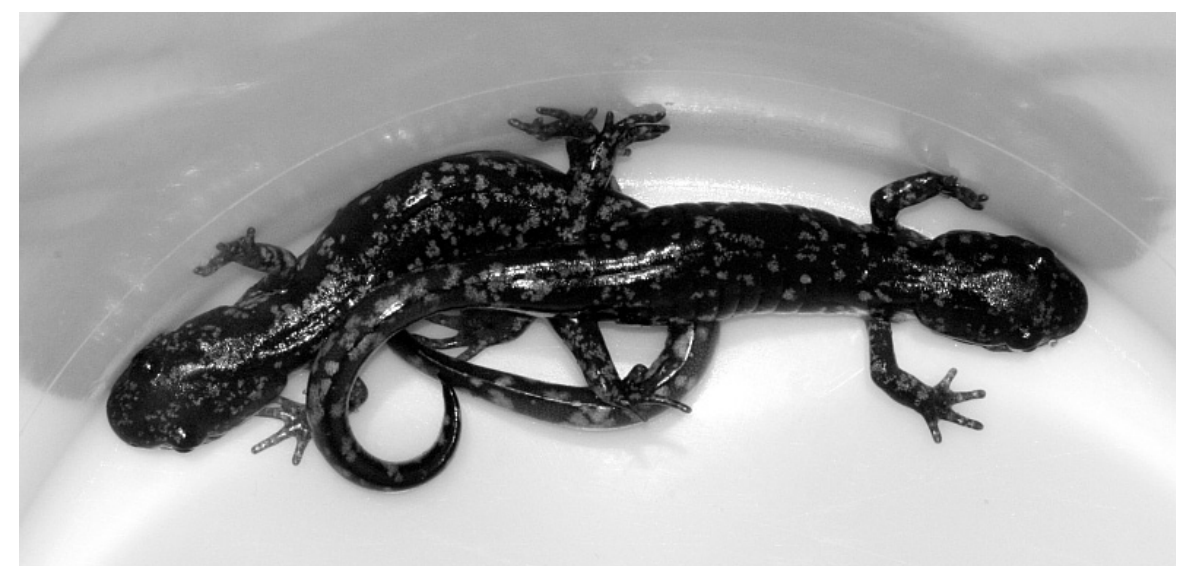

Figure 2: Blue-spotted salamander metamorphs (TL about $7 \mathrm{~cm}$ ), Pinawa MB, 24 August 2009 (temporarily captive). In comparison with Figure 1, note the proportionately larger head and smaller tail, prominent neck, and more extensive blue or grey spots.

\section{Study area}

The study area (Figure 3 ) is a stretch of Ara Mooradian Way between 1.1 and $2.5 \mathrm{~km}$ north of Provincial Road 211, just east of the Winnipeg River and $12 \mathrm{~km}$ west of Pinawa, and centred at $50.160^{\circ} \mathrm{N}$, $96.049^{\circ} \mathrm{W}$. The approximate limits of the observed salamander movements have the following Universal Transverse Mercator coordinates (North American Datum 1983, Zone 14): southern limit $710790 \mathrm{E}, 5559800 \mathrm{~N}$; northern limit $710740 \mathrm{E}, 5561200 \mathrm{~N}$.

Ara Mooradian Way has a paved surface $6 \mathrm{~m}$ wide and gravel shoulders about $1.5 \mathrm{~m}$ wide. The road bed within the study area is slightly raised above the surrounding area, with ditches about $2 \mathrm{~m}$ below the road surface. Habitat on the west side (adjoining the Winnipeg River) is moist, mature deciduous forest (primarily poplar, Populus sp.) with a sparse understory and low, herbaceous ground-cover on leaf litter. This area provides habitat for several amphibian species including blue-spotted salamanders, but it lacks breeding pools, and the ditch on the west side of the road is mostly dry year-round. Immediately east of the road is a ditch that normally contains standing water, at least in spring. East of this ditch is an electrical transmission-line corridor, approximately $40 \mathrm{~m}$ wide, with dense grassy and herbaceous ground-cover and some marshy patches. The width of the combined road and transmission-line corridor is $70 \mathrm{~m}$, representing a significant barrier to salamanders that typically migrate and disperse over distances of a few hundred metres. ${ }^{1}$ The area east of the transmission-line corridor is also mostly poplar-dominated forest, but has several small pools with beaver (Castor canadensis) activity, numerous dead trees, and some small cattail (Typha sp.) stands. The pools feed a stream that flows under the road to the Winnipeg River through a small ravine at the northern boundary of the study area. Farther south, the forest on the west side is reduced to a narrow strip as the road approaches the river.

The woodland pools and surroundings provide breeding habitat for many amphibians, as indicated by abundant calling wood frog (Lithobates sylvaticus), boreal chorus frog (Pseudacris maculata), spring peeper ( $P$. crucifer), and gray treefrog (Hyla versicolor), with smaller numbers of northern leopard frog $(L$. 


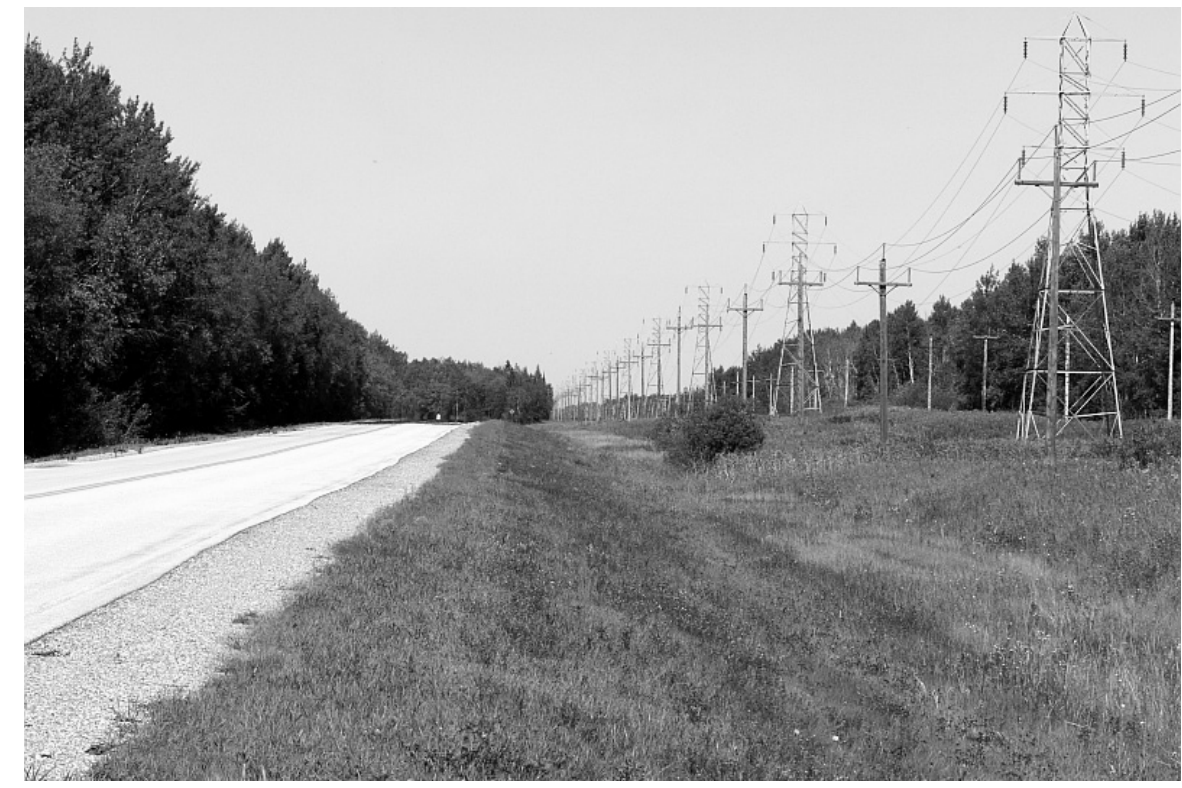

Figure 3: Study area, looking north along Ara Mooradian Way on 3 September 2012; from left to right are non-breeding forest habitat, road, power-line right-of-way, and presumed breeding forest habitat.

pipiens) and American toad (Anaxyrus americana). Boreal chorus frogs also breed at low-lying spots within the transmission corridor, and wood frogs are active in the east-side ditch, at least in wet springs. There are thus several potential breeding locations for salamanders east of the road, though breeding can only be inferred from the seasonal movements described below.

\section{Survey methods}

Blue-spotted salamanders were detected on the road surface when driving at about $20 \mathrm{~km} / \mathrm{h}$ with high-beam headlights. This was feasible because night traffic was minimal, with only three other vehicles being encountered in 53 surveys. Most surveys were conducted $1-4 \mathrm{~h}$ after sunset $(20: 30 \mathrm{~h}$ to $01: 00 \mathrm{~h})$ on evenings with light winds and temperatures above $5^{\circ} \mathrm{C}$. Periods immediately after substantial rainfall were selected where possible, but prevailing conditions in 2011-2012 were much drier than in 2008-2010, especially in early spring 2012 and late summer in both years. Round-trip surveys lasted between 10 and 50 minutes, depending on the number of salamanders found (up to 24).

When a salamander was seen the vehicle was stopped, and when possible the unrestrained animal's total length $(T L)$ was measured using a ruler. The accuracy of these measurements was limited by low lighting, parallax effects, and the movement or curved posture of some salamanders. Estimated uncertainties were $\pm 0.2 \mathrm{~cm}$ for stationary salamanders and up to $\pm 0.5 \mathrm{~cm}$ for moving ones. For surveys after 30 April 2011, when two-way movement was first noted, salamanders' orientation when first seen was also recorded. Most were oriented approximately perpendicular to the road direction. After measurement, salamanders were transferred gently to the grassy edge of the roadside shoulder in the direction they were facing when first seen.

Blue Jay 
Surveys were limited to the spring and late-summer/fall periods when maximum activity was expected, based on the Cameron woods study and research elsewhere. ${ }^{4,6,7}$ Extreme survey dates were 19 April - 2 June and 16 August - 13 October 2011, and 18 March - 22 May and 1 September - 17 October 2012.

\section{Results and Discussion}

Population demographics are difficult to establish for such inconspicuous species as small salamanders, and potential bias of sampling methods is always a concern. ${ }^{8}$ Passive, opportunistic studies of the type described here sample only the portion of the population that is on the move on a given night. Thus, they provide some insight into differential movement patterns among age classes, but they cannot yield relative populations of the age classes. Night-to-night fluctuations in numbers are at least partly weather-related, as described previously. ${ }^{4}$ Weather conditions may affect the amount of time individuals remain exposed on a road surface, as well as the number of animals on the move. The following discussion therefore emphasizes broad seasonal trends, using size distributions as a tool for comparison. Numerical results of the surveys are summarized in Table 1, and size/date information is presented in Figure 4. Altogether 268 salamanders were recorded along Ara Mooradian Way in 2011-2012, with at least one salamander recorded in 33 of 53 surveys $(62 \%$; see Table 1), compared with 195 salamanders in 45 of 75 surveys $(60 \%)$ at Cameron woods in 2008-2010. ${ }^{4}$ Usable TL measurements for inclusion in size analysis (see below) were obtained for 238 individuals. This total excludes four $(1.7 \%)$ with obviously damaged tails and 26 that were not measured for various reasons.

Movements were distributed along a 1.4-km stretch of road, with a broad peak in the central section but no hint of any narrow migration corridors. In spring surveys, larger numbers were observed in this study than at Cameron woods in 2008-2010: $75 \%$ of 32 surveys, with 8.8 salamanders per non-zero survey (NZS), compared with $38 \%$ of 13 surveys and 1.6 salamanders per NZS, respectively (Table 1). ${ }^{4}$ There were fewer non-zero surveys in late-summer and fall, but with comparable numbers between the two studies: $41 \%$ of 17 surveys with 6.8 salamanders per NZS in this study, compared with $73 \%$ of 49 surveys and 4.9 salamanders per NZS at Cameron woods. ${ }^{4}$

Measurements and inferences about age classes (see below) are consistent with previously published snout-tovent length (SVL) measurements. ${ }^{1}$ Assuming that SVL is about $57 \%$ of TL on average, ${ }^{4}$ published SVL measurements yield estimated TL ranges of 4.2-6.7 $\mathrm{cm}$ for metamorphs, $7.4-12.3 \mathrm{~cm}$ for adult males, and $8.9-13.5 \mathrm{~cm}$ for adult females. ${ }^{1}$ The overall size range for this study and Ref. 4 combined (5.0-14.0 $\mathrm{cm})$ agrees reasonably well with these estimates $(4.2-13.5 \mathrm{~cm})$.

No published measurements appear to exist for yearlings, other than those inferred in Ref. 4, but blue-spotted salamanders are believed to reach sexual maturity in the second year after hatching. ${ }^{1}$ Five individuals recorded in spring over the two studies with TL between 6.0 and $7.5 \mathrm{~cm}$ were assumed to be yearlings. Allowing for summer growth, it is likely that late-summer and fall individuals with TL around 8-10 cm (near the lower end of the adult size range) are also yearlings. A comparable size-based classification into three age classes (young of the year, juveniles, and adults) has been adopted for red-backed salamanders (Plethodon cinereus). ${ }^{8}$ In addition to small overall size, blue-spotted salamander metamorphs are distinguished from adults by their proportions and markings, as described in the caption to Figure 2. 
Table 1: Summary of survey results in two Pinawa-area studies (Ref. 4, Cameron woods, 2008-2010; this study, Ara Mooradian Way, 2011-2012). Figures in parentheses in the second and third columns are the numbers of non-zero surveys.

\begin{tabular}{|c|c|c|c|c|c|c|}
\hline \multirow{2}{*}{ Month } & $\begin{array}{l}\text { Number of } \\
\text { Surveys }\end{array}$ & $\begin{array}{l}\text { Maximum } \\
\text { Count }\end{array}$ & \multicolumn{4}{|c|}{ Total Count } \\
\hline & Ref. 4 & This Study & Ref. 4 & $\begin{array}{l}\text { This } \\
\text { Study }\end{array}$ & Ref. 4 & $\begin{array}{r}\text { This } \\
\text { Study }\end{array}$ \\
\hline March & $2(0)$ & $5(4)$ & 0 & 23 & 0 & 38 \\
\hline April & $7(4)$ & $16(12)$ & 3 & 24 & 7 & 127 \\
\hline May & $4(1)$ & $11(8)$ & 1 & 15 & 1 & 47 \\
\hline June & $5(1)$ & $2(0)$ & 2 & 0 & 2 & 0 \\
\hline July & $3(2)$ & $0(0)$ & 1 & -- & 2 & -- \\
\hline August & $13(10)$ & $2(2)$ & 8 & 4 & 31 & 6 \\
\hline September & $17(15)$ & $12(5)$ & 21 & 13 & 128 & 42 \\
\hline October & $19(11)$ & $5(2)$ & 5 & 6 & 19 & 8 \\
\hline November & $5(1)$ & $0(0)$ & 5 & -- & 5 & -- \\
\hline TOTAL & $75(45)$ & $53(33)$ & -- & -- & 195 & 268 \\
\hline \multicolumn{5}{|c|}{ Percentage of surveys with non-zero counts, March to May } & 38 & 75 \\
\hline \multicolumn{5}{|c|}{ Percentage of surveys with non-zero counts, August to } & 73 & 47 \\
\hline \multicolumn{5}{|c|}{ Number of salamanders per non-zero survey, March to May } & 1.6 & 8.8 \\
\hline \multicolumn{5}{|c|}{ Number of salamanders per non-zero survey, August to } & 4.9 & \\
\hline \multicolumn{5}{|c|}{$\begin{array}{r}\text { October } \\
\text { Average number of salamanders, all surveys, March to May }\end{array}$} & 0.6 & 6.6 \\
\hline \multicolumn{4}{|c|}{$\begin{array}{l}\text { Average number of salamanders, all surveys, March to May } \\
\text { Average number of salamanders, all surveys, August to }\end{array}$} & $\begin{array}{l}\text { August to } \\
\text { October }\end{array}$ & 3.6 & \\
\hline
\end{tabular}

Spring sightings almost exclusively involved adults, with the exceptions noted above. Excluding the presumed yearlings, TL measurements ranged from 9.0 to $14.0 \mathrm{~cm}$ and closely approximated a Gaussian distribution with a mean of 11.2 $\mathrm{cm}$ and a population standard deviation of $0.9 \mathrm{~cm}$. Results in 2011 and 2012 were virtually identical, and a combined distribution is shown in Figure 5, together with the late-summer/fall distribution of 2009-2010 data from the Cameron woods study. ${ }^{4}$ Males and females were not distinguished in the field, and there is no indication of separate peaks by gender in the size distribution. Instead, there is probably some peak broadening due to overlapping male and female size ranges. Fall sightings involved both metamorphs and adults, but few if any yearlings, as indicated by a bimodal size distribution with peaks at $T L=6$ and $11-12 \mathrm{~cm}$ and a minimum at $\mathrm{TL}=9 \mathrm{~cm}$ (Figure 6). This distribution is also evident in the clustering of late-summer/fall TL data into two size groups (right side of Figure 4). It differs markedly from the skewed distribution found at Cameron woods, extending from $\mathrm{TL}=5$ to $13 \mathrm{~cm}$, with a single peak at 6-7 cm (Figure 5). ${ }^{4}$

Data from Figures 5 and 6 were reduced to three age-class groups ( 5 to $7 \mathrm{~cm}, 8$ to $10 \mathrm{~cm}$, and 11 to $14 \mathrm{~cm}$ ) for a test to demonstrate that the large differences among the three size distributions are statistically significant (chi-squared test, $\left.X^{2}>100, d f=2, P<<0.1\right)$.

Initial spring movements, commencing in April 2011 and March 2012, were almost 


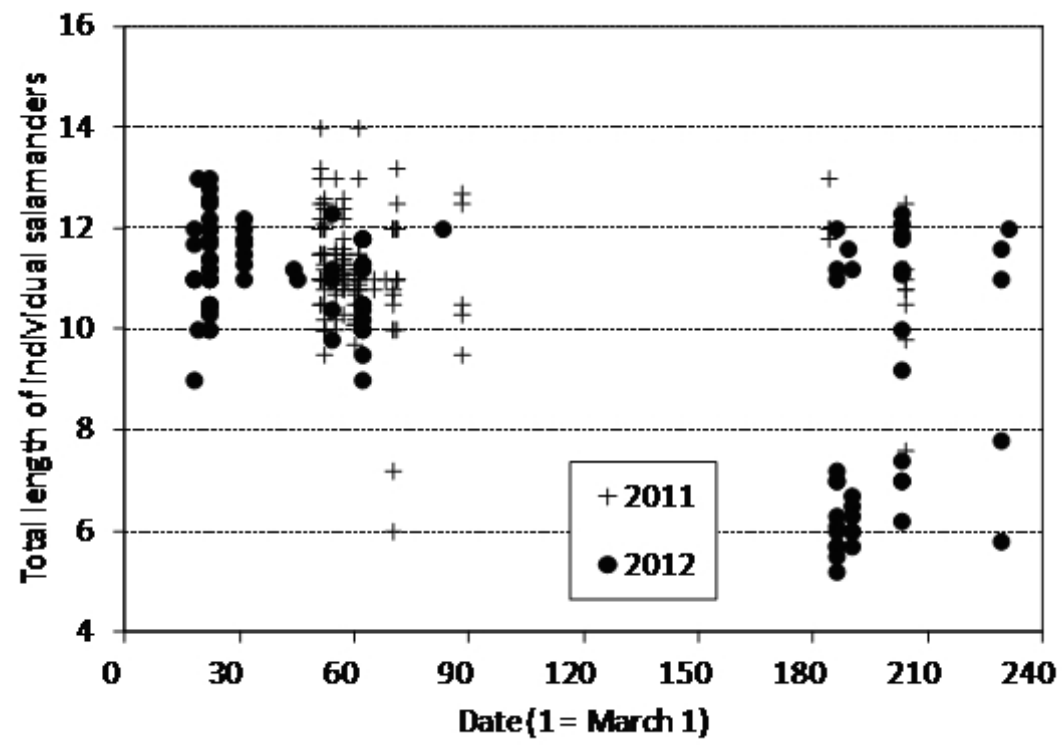

Figure 4:Sizes (total length) and dates of individual salamanders observed along Ara Mooradian Way, 2011 and 2012.

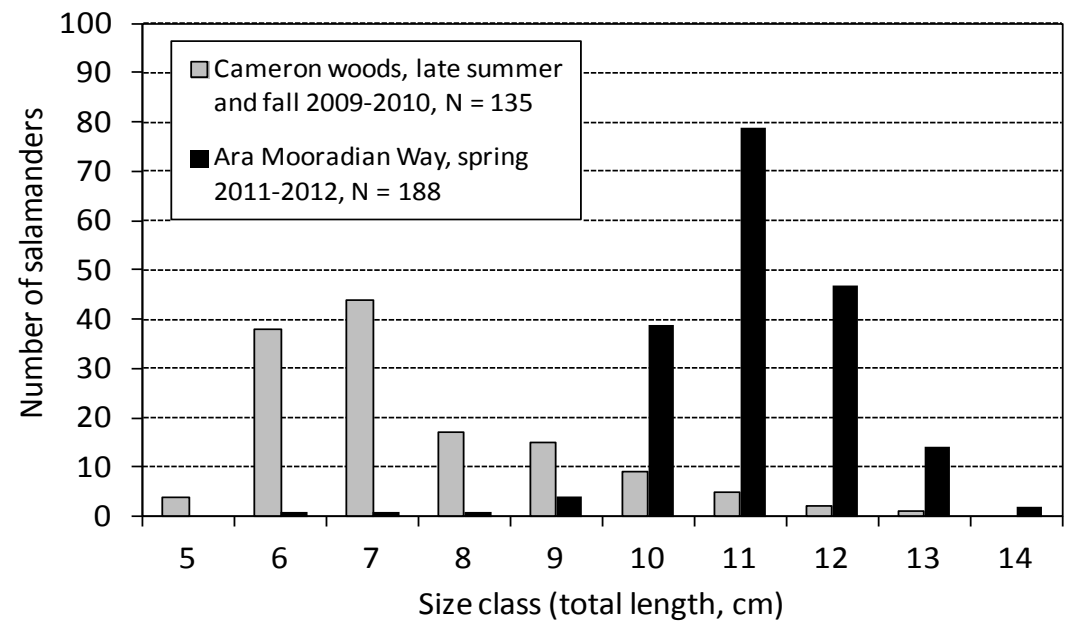

Figure 5: Size distributions of salamanders observed in spring along Ara Mooradian Way, 2011-2012, compared with late summer and fall at Cameron woods, 2009-2010. Size classes are based on uniform 1.0-cm intervals in TL, e.g., the value 9 represents $T L$ values between 8.5 and $9.5 \mathrm{~cm}$. 


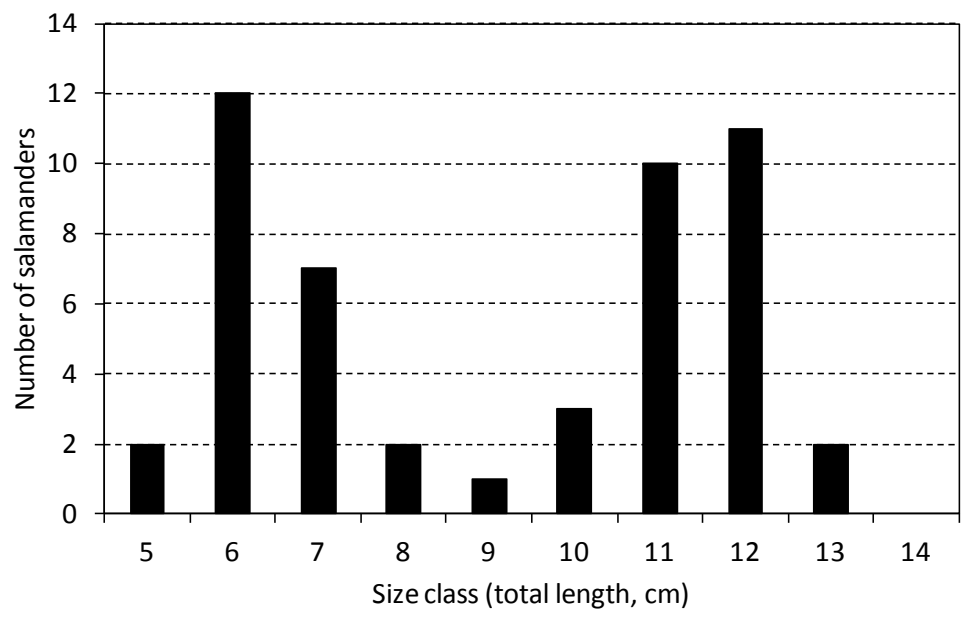

Figure 6: Size distribution of salamanders observed along Ara Mooradian Way in late summer and fall (31 August to 17 October) 2011 and $2012(N=50)$.

exclusively eastbound, i.e., towards the presumed breeding areas. Westbound, return movements were first noted on 30 April 2011 and 1 May 2012, and continued through May along with some eastbound salamanders. Fall movements of adults were bidirectional, but with roughly twice as many westbound as eastbound animals. Juvenile movements, observed mostly in 2012, were almost exclusively westbound, i.e., away from the presumed breeding habitat. The spring movements are similar to those observed by Regosin et al. in a two-year study at a breeding pond in Massachusetts, but they noted minimal fall movements of blue-spotted salamanders (unlike three other amphibian species in their study). ${ }^{6}$ Salamander movements near Cameron woods were much reduced in 2011-2012, compared with the numbers found in 2008-2010 (Ref. 4), presumably because of the drier conditions, and possibly also because of ongoing low-density residential development. In 2011-2012, only nine salamanders were observed in 15 walking surveys of the kind described in Ref. 4. Three such surveys were run on the same nights as three of the highest September counts along Ara Mooradian
Way (on 2, 6 and 19 September 2012); the three-night grand totals were one salamander near Cameron woods and 32 along Ara Mooradian Way. It is unfortunate that the Ara Mooradian Way site was discovered after the Cameron woods study was complete, limiting the direct comparisons. ${ }^{4}$

\section{Incidental observations}

Some of the spring salamander movements on Ara Mooradian Way coincided with similar migrations of other amphibians, especially wood frogs. Only a few other amphibians, mostly northern leopard frogs and American toads, were noted during late summer and fall surveys in both studies. Early emergence in 2012 was linked to an early thaw and mid-March heat wave that prompted record-early emergence of many amphibian and reptile species across southern Manitoba. ${ }^{5}$ For example, locally record-early wood frogs and bluespotted salamanders were observed on 18 March 2012, and boreal chorus frogs were detected the following day.

While evenings immediately after significant rainfall (at least a few $\mathrm{mm}$ ) 
were generally most productive, this was not a necessary condition for amphibian movements, as noted previously. ${ }^{4}$ In spring, it appeared to be sufficient for the habitat to be saturated by recent snowmelt. With one exception, salamanders appeared to be migrating or dispersing rather than hunting or feeding. On 1 May 2012, I found one salamander and one wood frog with half-swallowed earthworms. This was an evening with strong westward (post-breeding) movements of both species, as well as earthworm movement onto the wet road, suggesting opportunistic feeding by a few individual amphibians rather than deliberate hunting on the road surface.

Road mortality appeared to be low, consistent with light traffic, but three of six salamanders found on 15 October 2012 were dead. The small number of salamanders with obviously damaged tails $(1.7 \%$ of those measured) indicates low rates of conspecific aggression or predation, at least after metamorphosis, when compared with reported rates of 0 to $35 \%$ of red-backed salamanders with cut tails at various forest sites in Quebec. ${ }^{8,9}$

\section{Conclusions}

Different size distributions of salamanders observed in the two studies can be related to differing conditions at the two sites. Data from Cameron woods in 2008-2010 appear to represent mostly late-summer and fall dispersal movements near a partly isolated forest fragment, presumably during a period of high breeding success and elevated population density associated with exceptionally wet conditions. ${ }^{4}$ In contrast, the 2011-2012 data from Ara Mooradian Way reveal two-way spring migrations and fall dispersal movements in relatively dry years between non-breeding and breeding habitats in a forested area bisected by a road. These movements resemble those in studies elsewhere..$^{1,6,7}$ It is possible that reports of blue-spotted salamander migration as late as June in northerly parts of their range refer to return movements from breeding pools. ${ }^{1}$

1. Petranka JW (1998) Salamanders of the United States and Canada. Smithsonian Press, Washington DC and London, England.

2. Preston WB (1982) The Amphibians and Reptiles of Manitoba. Manitoba Museum of Man and Nature, Winnipeg, MB.

3. Hewson S, Watkins WG (2010) Update on the range and distribution of bluespotted salamanders in Manitoba. Blue Jay 68(4):184-189.

4. Taylor P (2010) Seasonal movements of blue-spotted salamanders at Pinawa, Manitoba. Blue Jay 68(4):190-198.

5. The Manitoba Herps Atlas, http://www. naturenorth.com/Herps/Manitoba_Herps_ Atlas.html.

6. Regosin JV, Windmiller BS, Homan RN, Reed JM (2005) Variation in terrestrial habitat use by four pool-breeding amphibian species. Journal of Wildlife Management 69:1481-1493.

7. Lowcock LA, Griffith H, Murphy RW (1992) Size in relation to sex, hybridity, and breeding dynamics in central Ontario populations of the Ambystoma jeffersonianum-laterale complex. Journal of Herpetology 26:46-53.

8. Moore J-D (2009), Comparison of a population of eastern red-backed salamanders, Plethodon cinereus, under native dominant wood coverboards and natural cover objects, Canadian FieldNaturalist 123(3):210-214.

9. Bonin J, Desroches J-F, Ouellet M, Leduc $A(1999)$, Les forêts anciennes : refuges pour les salamanders [Ancient forests: refuges for salamanders], Le Naturaliste canadien 123:13-18. 